DOI.

https://doi.org/10.22219/fths.v2i2

Received : Mei 2019

Accepted : Juni 2019

Available online: Juli 2019

\title{
Efek Penambahan Sari Buah Mengkudu (Morinda citrifolia L.) pada Roti Tawar terhadap Kadar Glukosa Darah Pada Tikus yang Diinduksi Aloksan
}

\author{
Nurul Laelatunisa ${ }^{1}$, Nikmatul Rizky $^{1}$, Rachmadanti Arum $^{1}$, Rista Anggriani ${ }^{*}$ \\ ${ }^{1}$ Program Studi Teknologi Pangan, Fakultas Pertanian Peternakan, Universitas Muhammadiyah \\ Malang, Malang, Indonesia \\ * Corresponding author email : $\underline{\text { rista@umm.ac.id }}$
}

\begin{abstract}
Noni (Morinda citrifolia L) has been known to have antihyperglycemic activity. Xeronine compounds, alkaloids, which play a role in controlling blood glucose. Previous research, researchers have made white bread with the addition of noni juice, but there has not been an analysis of its antihypergemic activity. So this study aims to determine the effect of white bread with the addition of noni juice $(50,150,250 \mathrm{ml})$ on the reduction of blood glucose in vivo. Male white mouse mice aged 3 months were grouped into 7 groups namely negative control, positive control, noni juice, noni juice without bread and noni juice with noni juice $(50,100$, and $150 \mathrm{~mL})$. All groups except the negative controls were induced with $200 \mu \mathrm{L}$ alloxan $45 \mathrm{mg} / \mathrm{kg}$ body weight until the rats were declared hyperglycemic (blood glucose $>135 \mathrm{mg} / \mathrm{dL}$ ). After that the rats were fasted, then blood glucose levels before and after being given bread were measured every 30 minutes until the 120 minutes. Blood glucose measurements are measured directly through the tail vein using a glucometer. In addition, white bread was also tested qualitatively alkaloids. All white bread with noni juice addition showed antihyperglicemic avctivity in varioius percentage. The highest percentage of blood glucose reduction after 60 minutes consumption was obtained in white bread with the addition of $250 \mathrm{~mL}$, amounted $37.65 \%$. White bread with the addition of noni juice indicated positive to alkaloid.

Keywords: decrease of blood glucose, noni juice, white bread
\end{abstract}

\section{PENDAHULUAN}

Roti tawar merupakan alternatif pengganti sumber energi selain nasi bagi mayoritas masyarakat. Roti putih yang merupakan jenis roti tawar selain roti gandum, mempunyai Indeks Glikemik (IG) yang tinggi dikarenakan roti mudah untuk dicerna sehingga gula akan mudah dipecah dan diserap oleh tubuh menghasilkan gula darah yang tinggi. Kategori indeks glikemik yang tinggi jika bernilai lebih dari 70 (Muflihati, 2017). Bahkan kedua jenis roti tawar tersebut mampu memberikan energi yang lebih banyak dibandingkan dengan 100 gram nasi putih atau mi basah (Direkrorat Gizi, depkes, 1992). Beras puith mempunyai IG 82, sedangkan beras pratanak mempunyai IG sekitar 60 (Diyah, $\mathrm{dkk}, 2016$;Widowati dkk, 2009). Hal ini yang menyebabkan roti tawar dihindari oleh penderita diabetes mellitus karena meningkatkan glukosa darah secara cepat. Oleh karena itu, beberapa penelitian memformulasikan roti tawar dengan 
bahan lain yang bersifat fungsional, seperti Sugiharto dkk (2016) yang menambahkan minyak ikan sebagai sumber antioksidan, Lestari dkk (2016) yang menambahkan tepung koro sebagai subtitusi terigu agar meningkatkan kandungan protein roti tawar.

Mengkudu (Morinda citrifolia $L$ ) dikenal masyarakat Indonesia memiliki banyak manfaat bagi kesehatan. Hal ini dikarenakan adanya kandungan senyawa metabolite sekunder, yang terlaporkan sebanyak 160 senyawa fitokimia terindentifikasi didalam buah mengkudu (Blanco et al,2006). Beberapa senyawa aktif yang ditemukan pada mengkudu diantaranya vitamin C, scopoletin, karoten, vitamin A, glikosida flavon, pro-xeronine dan terpenoid (Wang et al, 2002). Senyawa fitokimia yang terkandung dalam mengkudu yang memberikan efek antidiabetes adalah xeronine dan proxeronine yang merupakan golongan alkaloid (Potterat dan Hamburger, 2007). Meskipun mempunyai banyak manfaat kesehatan, mengkudu mempunyai aroma yang kuat ketika sudah mulai matang, yang kurang disukai oleh masyarakat. Sehingga mengkudu sering diolah hanya dalam bentuk sari mengkudu (Hardoko dkk, 2003); Sulistiowati, 2010). Sari mengkudu pernah diberikan ke tikus sebesar $2 \mathrm{~mL} / 200 \mathrm{~g}$ BB sebanyak dua kali selama 20 hari terbukti mampu menurunkan kadar glukosa darah hingga mencapai 150mg/dL (Nayak, dkk, 2010).

Oleh karena itu, perlu dilakukan analisa aktivitas penurunan glukosa darah dari roti tawar yang ditambahkan dengan sari mengkudu. Sehingga dapat dihasilkan bahan pangan dengan sisi fungsional yakni bersifat antihiperglikemik.

\section{METODE PENELITIAN}

Bahan

Buah mengkudu yang didapatkan dari pasar lokal Malang.

Alat

Peralatan yang digunakan untuk pembuatan roti antara lain oven manual dan dough mixer, sedangkan untuk pengujian in vivo menggunakan Blood Glucose Test Meter merk GlucoDr.

\section{Pembuatan sari mengkudu}

Pembuatan sari mengkudu dilakukan secara sederhana yakni dengan memeras buah mengkudu yang sudah matang secara manual, kemudian disaring untuk mendapatkan filtratnya.

\section{Pembuatan Roti Tawar dengan penambahan dari mengkudu}

Pembuatan roti tawar dimulai dengan penimbangan bahan seperti tepung, gula, ragi, sari mengkudu dengan perlakuan berbeda sebanyak $50 \mathrm{ml}, 150 \mathrm{ml}$, dan $250 \mathrm{ml}$ diaduk hingga rata dengan alat Dough mixer dengan speed 1, 
kemudian dimasukkan garam dan mentega hingga adonan kalis, lalu adonan dibulatkan memanjang dan digulung dan ditempatkan pada loyang untuk difermentasi selama 45 menit pada suhu ruang. Kemudian adonan dipanggang di oven pada suhu $200^{\circ} \mathrm{C}$ selama 30 menit. Roti tawar yang matang didinginkan dan dipotong potong menggunakan pisau pemotong roti tawar.

\section{Penyiapan Tikus Hiperglikemik dengan Induksi Aloksan}

Sebanyak 21 mencit putih yang berumur 3 bulan dengan berat rata-rata 25 g dibagi menjadi 7 kelompok. Enam kelompok perlakuan disuntik dengan aloksan $200 \mu \mathrm{L} 45 \mathrm{mg} / \mathrm{kg}$ BB agar berkondisi diabetes, 1 kelompok sisanya sebagai kelompok kontrol negatif tidak diinduksi. Lalu ditempatkan secara individu dalam kandang-kandang khusus yang terbagi dalam 7 kelompok perlakuan yang masing-masing terdapat 3 ekor sebagai ulangan. Mencit putih ditempatkan pada tempat yang bersih dalam suhu kamar dengan ventilasi dan pencahayaan yang cukup. Mencit putih yang telah ditempatkan dalam kandangkandang khusus selanjutnya diberi pakan pelet (Comfeed, Indonesia) masingmasing $5 \mathrm{~g}$ per saji dengan diberi minum secara ad libitum (tanpa batas) selama 6 hari.

\section{Uji aktivitas hipoglikemik Roti Tawar dengan Penambahan Sari Mengkudu}

Seluruh kelompok tikus dipuasakan selama 12 jam, kemudian kadar glukosa darah diukur. Kemudian masing-masing kelompok diberikan konsumsi berupa aquades untuk kelompok kontrol negatif, metformin sejumlah untuk kontrol positif, roti tawar sebanyak $2,1 \mathrm{~g}$ secara ad libitum untuk kelompok perlakuan 1 sampai 4 (roti tawar tanpa penambahan sari mengkudu dan dengan penambahan sari mengkudu 50,150,250 mL), dan 0,2 mL sari mengkudu untuk kelompok perlakuan 5. Kemudian masing-masing kelompok diukur kadar glukosa darahnya pada menit ke 30 dan 60. Pengukuran dilakukan dengan cara melukai ekor dan dipijat dengan pelan agar keluar darah, kemudian darah diteteskan pada Glucose Test Strip dan dibaca menggunakan alat glukometer. Data yang didapatkan merupakan kadar glukosa darah (mg/dL). Persentase kenaikan dan penurunan dihitung dengan rumus:

\%penurunan glukosa darah $=($ glukosa darah menit ke $30-$ glukosa darah menit ke 60$) \times 100 \%$ glukosa darah menit ke 30

\section{Uji kualitiatif alkaloid}

Uji alkaloid dilakukan dengan metode Dragendorff. Sampel sebanyak 3 mg diletakkan dalam tabung reaksi kemudian ditambahkan methanol sebanyak $5 \mathrm{~mL}$, lalu ditambahkan $3 \mathrm{ml}$ ammonia sampai $\mathrm{pH}$ 8-9. Ekstrak methanol 
tersebut disaring kemudian ditambahkan $2 \mathrm{ml}$ asam sulfat dan dikocok untuk mendapatkan 2 lapisan. Lapisan atas (sulfat) diambil 5 tetes kemudian diberi 1 tetes pereaksi Dragendorf \& terbentuknya endapan jingga menunjukkan adanya alkaloid (Suryani, 1991).

\section{Rancangan Percobaan dan Analisa Data}

Rancangan percobaan yang digunakan adalah rancangan percobaan deskriptif. Data glukosa darah disajikan sebagai rata-rata (Standard error of mean/SEM), sedangkan data presentase penurunan dianalisa dengan ANOVA dan diikuti dengan uji lanjut BNT dengan $\mathrm{p}<0,05$. Sementara data alkaloid disajikan secara deskriptif kualitatif.

\section{HASIL DAN PEMBAHASAN}

\section{Aktivitas Hipoglikemik Roti Tawar dengan Penambahan Sari Mengkudu}

Hasil uji aktivitas hipoglikemik sari mengkudu yang ditambahkan pada roti tawar dapat dilihat pada Tabel 1. Variasi waktu digunakan untuk mengetahui efek jangka pendek konsumsi roti tawar dengan penambahan sari mengkudu terhadap glukosa darah hewan coba, sedangkan variasi volume sari mengkudu pada roti tawar digunakan untuk mengetahui tren penurunan glukosa darah. Pada perlakuan 5 untuk mengetahui aktivitas hipoglikemik sari mengkudu sebelum dijadikan produk olahan lain.

Tabel 1. Kadar Glukosa Darah menit ke 30 dan 60 pada Masing-Masing Kelompok Perlakuan

\begin{tabular}{l|l|l|l}
\hline \multirow{2}{*}{ Kelompok } & \multicolumn{3}{|c}{ Kadar Glukosa Darah (mg/dL) } \\
\cline { 2 - 4 } & \multicolumn{1}{|c|}{$\begin{array}{c}\text { 0 menit } \\
\text { (puasa) }\end{array}$} & $\begin{array}{c}30 \text { menit } \\
\text { setelah } \\
\text { makan }\end{array}$ & $\begin{array}{c}\text { 60 menit } \\
\text { setelah } \\
\text { makan }\end{array}$ \\
\hline Kontrol Negatif & $105 \pm 8,19$ & $109 \pm 2,52$ & $120 \pm 8,08$ \\
Kontrol Positif & $201 \pm 83,51$ & $111 \pm 23,43$ & $108 \pm 18.93$ \\
Perlakuan 1 (RT tanpa SM) & $90 \pm 34.53$ & $131 \pm 22,50$ & $179 \pm 78,59$ \\
Perlakuan 2 (RT dengan SM 50 mL) & $150 \pm 28,93$ & $216 \pm 37,99$ & $181 \pm 22,23$ \\
Perlakuan 3 (RT dengan SM 150 mL) & $137 \pm 48,03$ & $463 \pm 237,29$ & $348 \pm 211,20$ \\
Perlakuan 4 (RT dengan SM 250 mL) & $143 \pm 43,59$ & $228 \pm 34,27$ & $143 \pm 39,93$ \\
Perlakuan 5 (SM 0,2 mL) & $188 \pm 58,97$ & $200 \pm 26,50$ & $102 \pm 16,86$ \\
\hline Ketaranan :
\end{tabular}

Keterangan : RT = Roti Tawar, SM = Sari Mengkudu

Gambar 1 menunjukkan representasi dari Tabel 1 dalam bentuk grafik garis. Pada menit ke 0, kelompok kontrol negatif, hewan coba tidak diinduksi aloksan sehingga glukosa darah mencit puasa pada menit ke 0 berada pada kisaran normal yakni sekitar $105 \mathrm{mg} / \mathrm{dL}$. Menurut Departemen Kesehatan (2005), klasifikasi diagnosis keadaan normal apabila glukosa darah < $100 \mathrm{mg} / \mathrm{dL}$. 
Sedangkan menurut Hans Tandra (2007), kadar glukosa darah stabil sekitar 70$110 \mathrm{mg} / \mathrm{dL}$. Kondisi ini berlanjut sampai menit ke 60 yang menunjukkan kadar glukosa darah masih dalam kondisi normal. Sedangkan pada 6 kelompok lainnya, kadar glukosa darah puasa mencit pada menit ke 0 dikategorikan sebagai kondisi diabetes, karena berada kisaran $\geq 126 \mathrm{mg} / \mathrm{dL}$ (Departemen Kesehatan, 2005). Tikus dinyatakan hiperglikemik apabila kadar glukosa darah $>135 \mathrm{mg} / \mathrm{dl}$ (Girl, 2008). Kondisi hiperglikemik ini disebabkan oleh induksi aloksan. Senyawa aloksan merupakan salah satu zat diabetogenik yang bersifat toksik, terutama terhadap sel beta pankreas, sehingga menyebabkan hewan coba menjadi diabetes (Szkuldeski, 2002).

Pada kelompok kontrol positif, metformin $45 \mathrm{mg} / \mathrm{kg}$ BB mampu menurunkan glukosa darah dari mencit yang hiperglikemik sampai pada konsentrasi normal yakni $105 \mathrm{mg} / \mathrm{dL}$ hanya dalam waktu 30 menit. Hal ini dikarenakan metformin merupakan obat antidiabetes yang melalui stimulasi glikolisis langsung pada jaringan perifer dengan pengeluaran glukosa dari darah, mengurangi glukoneogenesis hati, memperlambat absorbs glukosa darah, pengurangan glukagon pada plasma dan meningkatkan pengikatan insulin pada reseptor insulin (Katzung, 2007).

Pada kelompok perlakuan 1 sampai 4, setelah 30 menit diberi konsumsi sari mengkudu maupun roti tawar yang ditambahkan sari mengkudu, kadar glukosa darah mengalami peningkatan. Peningkatan terbesar pada perlakuan 3 (Roti Tawar dengan $150 \mathrm{~mL}$ sari mengkudu) dan peningkatan terkecil pada perlakuan 5 (sari mengkudu 0,2 mL). Kemudian 60 menit setelah itu, glukosa darah mengalami penurunan, bahkan hampir menuju pada konsentrasi glukosa darah semula.

Penurunan glukosa darah ini diduga kuat dari pengaruh sari mengkudu. Hal ini terbukti pada perlakuan 5, mencit hiperglikemik setelah 60 menit mengkonsumsi sari mengkudu mampu menurunkan glukosa darah sampai pada kondisi normal yakni sekitar $100 \mathrm{mg} / \mathrm{dL}$. Hal ini selaras dengan Nayak, dkk (2010) yang memberikan sari ke tikus sebesar $2 \mathrm{~mL} / 200 \mathrm{~g}$ BB sebanyak dua kali selama 20 hari terbukti mampu menurunkan kadar glukosa darah hingga mencapai 150mg/dL. Menurut Potterat dan Hamburger (2007) mengkudu mempunyai senyawa xeronine yang merupakan alkaloid. Senyawa ini mampu mempengaruhi metablisme dalam tubuh untuk menurunkan glukosa darah. Alkaloid mempunyai kemampuan untuk meregenerasi sel beta pankreas yang rusak (Arjadi dan Susatyo, 2010; Nayak, dkk, 2010). Hal ini didukung dengan data uji alkaloid pada Tabel 3 . 


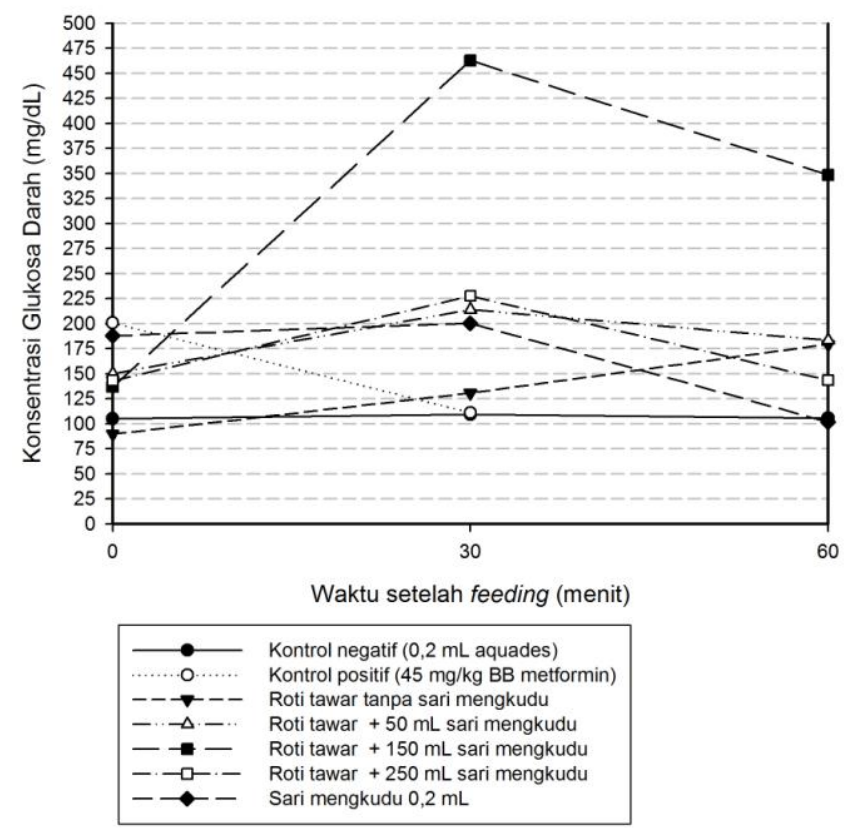

Gambar 1. Rata-Rata Perubahan Glukosa Darah Mencit (mg/dL) yang Diinduksi Hiperglikemik akibat Beberapa Perlakuan.

Perbandingan kemampuan aktivitas hipoglikemik antara kelima perlakuan dalam menurunkan glukosa darah dapat dilihat pada Tabel 2. Pada perlakuan 1, kadar glukosa darah terus mengalami kenaikan sampai menit ke 60, sedangkan pada perlakuan 2 sampai 4 kadar glukosa darah mengalami penurunan setelah menit ke 30. Semakin banyak volume sari mengkudu yang ditambahkan, maka persentase penurunan glukosa darah juga semakin besar. Akan tetapi, persentasenya lebih rendah dibandingkan perlakuan $5(0,2 \mathrm{~mL}$ sari mengkudu) menunjukkan penurunan paling besar sampai $49,32 \%$.

Tabel 2. Rata-Rata Presentase Penurunan Glukosa Darah Pasca Konsumsi Roti Tawar

\begin{tabular}{l|r}
\hline Kelompok & $\begin{array}{c}\text { \% Penurunan } \\
\text { (dari menit 30 ke 60) }\end{array}$ \\
\hline Perlakuan 1 (RT tanpa SM) & $15,10 \mathrm{a}$ \\
Perlakuan 2 (RT dengan SM 50 mL) & $26,90 \mathrm{~b}$ \\
Perlakuan 3 (RT dengan SM 150 mL) & $37,65 \mathrm{c}$ \\
Perlakuan 4 (RT dengan SM 250 mL) & $49,32 \mathrm{~d}$ \\
Perlakuan 5 (SM 0,2 mL)
\end{tabular}

Nilai diatas merupakan rata-rata dari tiga mencit. Nilai rata-rata dengan diikuti angka berbeda menunjukkan perbedaan yang nyata $(p<0.05)$

Keterangan $: \mathrm{RT}=$ Roti Tawar, $\mathrm{SM}=$ Sari Mengkudu 
Lebih rendahnya persentase penurunan glukosa darah pada roti tawar yang ditambahkan dengan sari mengkudu $250 \mathrm{~mL}$ dibanding sari mengkudu 0,2 $\mathrm{mL}$ menunjukkan bahwa senyawa bioaktif di mengkudu yang berperan sebagai antihiperglikemik mengalami perubahan kemampuan setelah diolah ke roti tawar. Pada penelitian Wati, dkk (2018), membuktikan bahwa adanya alkaloid pada buah naga merah yang lebih stabil disimpan pada suhu dingin daripada suhu ruang.

Meskipun demikian, nilai persentase penurunan glukosa darah pada roti tawar dengan penambahan sari mengkudu diatass $250 \mathrm{~mL}$ lebih tinggi jika dibandingkan cuka salak (29,41\%); ekstrak etanol daun kembang bulan (21,16\%), ekstrak daun insulin (29,04\%) (Zubaidah dkk, 2013; Darmawi dkk, 2015; Astuti, 2012). Meskipun presentase penurunan glukosa darah oleh perlakuan 2-4 (roti tawar dengan penambahan sari mengkudu) tidak sebesar dengan perlakuan 5 (sari mengkudu) yang mampu mencapai $49,32 \%$, produk roti tawar mengkudu ini mempunyai kemampuan menurunkan glukosa darah pasca 60 menit konsumsi jika dibandingkan dengan produk roti tawar tanpa sari mengkudu.

\section{Kandungan Alkaloid pada Roti Tawar dengan Penambahan Sari Mengkudu}

Pada roti tawar yang ditambahkan sari mengkudu menunjukkan adanya kandungan alkaloid yang ditunjukkan dengan adanya warna jingga yang terbentuk pada hasil uji kualitatif dengan menggunakan metode Dragendorf.

Tabel 3. Hasil Uji Kualitatif Alkaloid pada Roti Tawar dengan atau tanpa Penambahan Sari Mengkudu

\begin{tabular}{l|r|r}
\hline $\begin{array}{l}\text { Uji Alkaloid } \\
\text { (metode Dragendorf) }\end{array}$ & Warna & Intensitas \\
\hline Roti Tawar dengan $50 \mathrm{~mL}$ sari mengkudu & Jingga & ++ \\
Roti Tawar dengan $150 \mathrm{~mL}$ sari mengkudu & Jingga & +++ \\
Roti Tawar dengan $250 \mathrm{~mL}$ sari mengkudu & Jingga & ++++ \\
Sari Mengkudu & Jingga & ++++ \\
\hline
\end{tabular}

Keterangan :++ : rendah; +++ : medium; ++++ : kuat

Penurunan glukosa darah mencit pasca mengkonsumsi roti tawar dengan penambahan sari mengkudu disebabkan adanya kandungan senyawa xeronine yang bersifat antidiabetes yang merupakan golongan alkaloid (Potterat dan Hamburger, 2007). Xeronine merupakan alkaloid hasil konversi dari precursor alami pada mengkudu yakni proxeronine. Xeronine dipercaya untuk membantu penurunan tekanan darah tinggi dan glukosa darah (Wang et al, 2002). Untuk membuktikan adanya senyawa ini, maka dilakukan uji secara kualitatif alkaloid. Hasil menunjukkan, bahwa semakin banyak sari mengkudu yang ditambahkan, maka intensitas warna jingga semakin kuat. Berdasarkan uji Dragendorf warna 
jingga menunjukkan adanya alkaloid dalam roti tawar tersebut (Marliana dkk, 2015). Hal ini mendukung pernyataan Gambar 1 dan Tabel 2 bahwa semakin banyak sari mengkudu yang ditambahkan pada roti tawar, maka kemampuan menurunkan glukosa darah pada mencit semakin besar.

\section{KESIMPULAN}

Penambahan $250 \mathrm{~mL}$ sari mengkudu pada roti tawar memberikan aktivitas penurunan glukosa darah sampai 37,65\% pasca 60 menit konsumsi. Senyawa metabolit sekunder alkaloid terdeteksi pada roti tawar yang ditambahkan sari mengkudu. Dari hasil penelitian tersebut dapat disimpulkan bahwa sari mengkudu pada roti tawar bertindak sebagai agen antihiperglikemik untuk menurunkan glukosa darah.

\section{REFERENSI}

Arjadi, F., dan P.Susatyo. 2010. Regenerasi sel pulau langerhans pada tikus putih (Rattus novergicus) diabetes yang diberi rebusan daging mahkota dewa (Phaleria macrocarp lam). Journal of medicine and Health.Vol 2. No 2

Astuti, Vicoria Cyntia Yogya. 2012. Pengaruh Pemberian Ekstrak Daun Kumis Kucing (Orthosiphon aristatus) Terhadap Penurunan Kadar Glukosa Darah Tikus Wistar Yang Diinduksi. Skripsi Penelitian. Universitas Dipenogoro akultas Kedokteran.

Blanco, Y.C.,Vaillant,F., Perez, A.M., Reynes, M., Brillouet, J.M., and Brat, P. 2005. The noni fruit (Morinda citrifolia L): a review of agricultural research nutritional and theraupetic properties. Journal of Food Composition and analysis.Vol 19, Issues 6-7, 645-654

Darmawi, Ary Rizki., Chairul, S., Rudi, K. 2015. Aktivitas Antihiperglikemik Dari Ekstrak Etanol dan $n$-Heksana Daun Kembang Bulan [Tithonia diversifolia A.Gray] Pada Tikus Putih Jantan. Jurnal Kimia Mulawarman Volume 12 Nomor 2

Departemen Kesehatan Republik Indonesia. 2005. Pharmaceutical Care untuk Penyakit Diabetes Melitus.Jakarta. Departemen Kesehatan RI

Direktorat Gizi Departemen Kesehatan R.I. 1992. Komposisi Mie Instan. Bhratara.Jakarta

Diyah, N.W., Aprilia, A., Gita, M.W., Greta, N., Eriza, T. H., Rany, W., Deka, P., Robi'atul, F. H, dan Purwanto. 2016. Evaluasi Kandungan Glukosa Dan Indeks Glikemik Beberapa Sumber Karbohidrat Dalam Upaya Penggalian Pangan Ber-Indeks Glikemik Rendah. Jurnal Farmasi Dan Ilmu Kefarmasian Indonesia Vol. 3 No. 2

Girl,L.N. 2008. Potensi Antioksidasi Daun Salam: Kajian In Vivo pad tikus Putih Hiperkoleterolemia dan Hiperglikemia. Skripsi. Fakultas Matematika dan Ilmu Pengetahuan Alam. Bogor

Hans, T. 2207. Diabetes. Jakarta: PT.Gramedia hal 22 
Hardoko , Adolf, P, dan Ivonne, P. K. 2003. Mempelajari Karakteristik Sari Buah Dari Mengkudu (Morinda citrifolia Linn.) yang Dihasilkan Melalui Fermentasi. Jurnal. Teknol. dan Industri Pangan, Vol. XIV, No. 2

Katzung, B.G.2007. Pancreatic Hormones and Antidiabetic Drugs. In : Basic and Clinical Pharmacology 10 th Ed Chapter 41: 683-705

Lestari, C.A., Tantan, W., dan Hasnelly. 2016. Pengaruh Substitusi Tepung Kacang Koro Pedang (Canavalia ensiformis) Terhadap Karakteristik Roti Tawar. Jurnal Penelitian Tugas Akhir

Marliana, S.D., Venty, S., dan Suyono. 2005. Skrining fitokimia dan analisis kromatografi lapis tipis komponen kimia buah labu siam (Sechium edule jacq. swartz.) dalam ekstrak etanol. Biofarmasi 3 (1): 26-31

Muflihati, I. 2017. Perlakuan Pada Roti Gandum Untuk Menurunkan Indeks Glikemiknya. Jurnal Ilmu Pangan dan Hasil Pertanian Vol. 1 No. 2

Nayak, B.Shivananda, Marshall, Julien, R., Isitor, Godwin and Adogwa, Andrew. 2010. Hypoglycemic and Hepatoprotective Activity of Fermented Fruit Juice of Morinda citrifolia (Noni) in Diabetic Rats. Evidence-Based Complementary and Alternative Medicine. Vol 2011 No 875293

Potterat $\mathrm{O}$ and Hamburger M. 2007. Morinda citrifolia (noni) fruit phytochemistry, pharmacology, safety. Planta Med. J. 73: 191-199.

Sugiharto, R., Dyah, K., dan Tias, A. 2016. Efek Penambahan Antioksidan Terhadap Sifat Sensori dan Lama Simpan Roti Tawar yang Difortifikasi Dengan Minyak Ikan. Jurnal Teknologi Industri \& Hasil Pertanian Vol. 21 No.2

Sulistiowati, N.A., 2010. Pengaruh Sari Buah Mengkudu (Morinda citrofolia) Terhadap Kadar Glukosa Darah Pada Penderita Diabetes Mellitus Tipe II. Skripsi. Jurusan Ilmu Kesehatan Masyarakat. Universitas Negeri Semarang.

Suryani, H. 1991. Kimia dan Sumber Daya Alam. Pusat Penelitian Universitas Andalas.Padang

Szkuldeski, T. 208. The mechanism alloxan and streptozotocin action in 8 cells of the rat pancreas. Physiol. Res. $50: 536-546$

Wang M-Y, West BJ, Jensen CJ, Nowicki D, Su C, Paul AK, Anderson G. 2002. Morinda citrifolia (Noni): a literature review and recent advances in Noni research. Acta Pharmacol Sin 23(12):1127-1141

Wati, E.W., Nur, M., dan Mirhansyah, A. 2018. Pengaruh Suhu dan Lama Penyimpanan Terhadap Stabilitas Warna Sari Buah Naga Merah (Hylocereus polyrhizus Brriton and Rose). Proceeding of the 8th Mulawarman Pharmaceuticals Conferences 30 ISSN: 2614-4778

Widowati, S., B.A.S. Santosa, M. Astawan, dan Akhyar. 2009. Penurunan indeks glikemik berbagai varietas beras melalui proses pratanak. Jurnal Pascapanen Pertanian 6(1): 1-9.

Zubaidah, E., Putri, W.D.R., Lyrawati, D., dan Widyaningtyas, D. 2013. Potensi cuka salak (Salaca vinegar) agen terapi hiperglikemia dan dislpidemia pada model tikus wistar diabetes. Jurnal Teknologi Pertanian. Vol 14 No.3 